\title{
Eksistensi Dan Keabsahan Surat Keputusan Bersama 3 Menteri Tentang Penjatuhan Sanksi Terhadap Pegawai Negeri Sipil
}

\author{
Ridwan \\ Fakultas Hukum Universitas Islam Indonesia Yogyakarta Indonesia \\ Jln. Tamansiswa No. 158 Yogyakarta Indonesia \\ ridwan@uii.ac.id
}

Received: 23 Desember 2020; Accepted: 20 Januari 2021; Published: 16 Maret 2021

DOI: 10.20885/iustum.vol28.iss1.art1

\begin{abstract}
This study analyzes the Joint Ministerial Decree (SKB) of 3 Ministers on the imposition of sanctions against Civil Servants (PNS) who commit criminal acts of occupational crimes or crimes related to their positions. This is a normative research, with a statutory approach and conceptual approach. The results of this study conclude that this SKB is a policy regulation that becomes a guideline for Civil Service Officers in imposing sanctions on civil servants. This SKB is in accordance with legal principles, does not contradict statutory regulations, and does not violate AUPB, unless if it is enforced retroacively.
\end{abstract}

Key Words: Bureaucratic reformation; existence; civil servants; Civil Service Agency

\section{Abstrak}

Penelitian ini menganalisis Surat Keputusan Bersama (SKB) 3 Menteri tentang penjatuhan sanksi terhadap Pegawai Negeri Sipil (PNS) yang melakukan tindak pidana kejahatan jabatan atau tindak pidana kejahatan yang ada hubungannya dengan jabatan. Penelitian ini merupakan penelitian normatif, dengan pendekatan perundang-undangan (statute approach) dan pendekatan konseptual (conceptual approach). Hasil penelitian ini menyimpulkan bahwa SKB 3 Menteri ini merupakan peraturan kebijakan yang menjadi pedoman bagi Pejabat Pembina Kepegawaian dalam menjatuhkan sanksi terhadap PNS. SKB 3 Menteri ini sesuai dengan asas hukum, tidak bertentangan dengan peraturan perundang-undangan, dan tidak melanggar AUPB, kecuali jika diberlakukan mundur.

Kata-kata Kunci: Eksistensi; aparatur negara; reformasi birokrasi; badan kepegawaian negara 


\section{Pendahuluan}

Surat Keputusan Bersama Menteri Dalam Negeri, Menteri Pendayagunaan Aparatur Negara dan Reformasi Birokrasi, dan Kepala Badan Kepegawaian Negara No. 128/6597/SJ, No. 15 Tahun 2018, No. 153/KEP/2018 tentang Penegakan Hukum Terhadap PNS Yang Telah Dijatuhi Hukuman Berdasarkan Putusan Pengadilan Yang Berkekuatan Hukum Tetap Karena Melakukan Tindak Pidana Kejahatan Jabatan Atau Tindak Pidana Kejahatan Yang Ada Hubungannya Dengan Jabatan (selanjutnya ditulis SKB 3 Menteri) disahkan pada 13 September 2018.

Sejak SKB 3 Menteri tersebut ditetapkan, kian muncul beragam reaksi terhadap pemberlakuannya. Ada yang menganggap SKB 3 Menteri ini melanggar hak asasi manusia, ada yang menilai bertentangan dengan UU No. 12 Tahun 2011 tentang Pembentukan Peraturan Perundang-undangan, sebagaimana telah diubah dengan UU No. 15 Tahun 2019 tentang Perubahan Atas UU No. 12 Tahun 2011 tentang Pembentukan Peraturan Perundang-undangan (selanjutnya ditulis UU P3), dan ada pula yang menduga mengandung unsur sewenang-wenang (willekeur). Ribuan Aparatur Sipil Negara (ASN) yang terpidana tindak pidana korupsi ramai-ramai mengajukan gugatan ke PTUN dan judicial review ke Mahkamah Agung. Sebagian Pejabat Pembina Kepegawaian (PPK) selaku pejabat yang berwenang (PyB) menjatuhkan hukuman dan/atau pejabat yang diinstruksikan memberlakukan SKB 3 Menteri ini ada yang ragu, namun banyak pula yang memberlakukan surut (terugwerkend).

Kemunculan SKB 3 Menteri tersebut sebenarnya harus dibaca dalam konteks penerapan ketentuan Pasal 87 ayat (2) UU No. 5 Tahun 2014 tentang Aparatur Sipil Negara yang di dalamnya disebutkan bahwa; "PNS dapat diberhentikan dengan hormat atau tidak diberhentikan karena dihukum penjara berdasarkan putusan pengadilan yang telah memiliki kekuatan hukum tetap karena melakukan tindak pidana dengan hukuman pidana penjara paling singkat 2 (dua) tahun dan pidana yang dilakukan tidak berencana" dan Pasal 87 UU No. 5 Tahun 2014 ayat (4) huruf b dan d yaitu tentang alasan pemberhentian PNS tidak dengan hormat, karena “Dihukum penjara atau kurungan berdasarkan putusan pengadilan yang telah memiliki kekuatan hukum tetap karena melakukan tindak pidana kejahatan jabatan atau tindak pidana kejahatan yang ada hubungannya 
dengan jabatan dan/atau pidana umum", 1 atau karena "dihukum penjara berdasarkan putusan pengadilan yang telah memiliki kekuatan hukum tetap karena melakukan tindak pidana dengan pidana penjara paling singkat 2 tahun dan pidana yang dilakukan dengan berencana". Ketentuan yang sama tentang alasan pemberhentian PNS tidak dengan hormat tersebut juga diatur dalam Pasal 247 sampai Pasal 252 PP No. 11 Tahun 2017 tentang Manajemen Pegawai Negeri Sipil.

Pemberian hukuman bagi PNS itu baik karena pelanggaran terhadap Peraturan Disiplin ataupun melakukan tindak pidana, dilakukan dengan instrumen keputusan (beschikking) yang dikeluarkan oleh pejabat yang berwenang memberikan hukuman. Khusus untuk penjatuhan hukuman karena pelanggaran disiplin, ketentuannya disebutkan secara jelas dalam Pasal 31 ayat (1) PP No. 53 Tahun 2010 tentang Disiplin Pegawai Negeri Sipil, "Setiap penjatuhan hukuman disiplin ditetapkan dengan keputusan pejabat yang berwenang menghukum".

Berdasarkan UU No. 5 Tahun 2014 tentang Aparatur Sipil Negara (ASN), pejabat yang berwenang menghukum itu implisit pada pejabat yang berwenang (PyB) yaitu pejabat yang mempunyai kewenangan melaksanakan proses pengangkatan, pemindahan, dan pemberhentian Pegawai ASN sesuai dengan ketentuan peraturan perundang-undangan, sebagaimana disebutkan dalam Pasal 1 angka 16, yang disebut juga dengan Pejabat Pembina Kepegawaian. Dengan merujuk pada Pasal 53 UU No. 5 Tahun 2014, Pejabat Pembina Kepegawaian itu terdiri atas Presiden, Menteri, Sekretaris Jenderal, Gubernur, Bupati atau Walikota.

Dikeluarkannya keputusan tentang hukuman bagi PNS karena pelanggaran terhadap Peraturan Disiplin itu mekanisme dan prosedurnya telah diatur secara jelas dalam Pasal 23 sampai dengan Pasal 31 PP No. 53 Tahun 2010 tentang Disiplin PNS, termasuk prosedur Upaya Administratif yang diatur dalam Pasal 32 sampai dengan Pasal 42 PP No. 53 Tahun 2010. Adapun keputusan pemberian hukuman karena PNS melakukan tindak pidana sebagaimana ketentuan Pasal 87 ayat (2), Pasal 87 ayat (4) huruf b dan huruf d UU No. 5 Tahun 2014, Pasal 247 dan

\footnotetext{
${ }^{1}$ Berdasarkan putusan MK No. 87/PUU-XVI/2018, frase “dan/atau pidana umum” telah ditiadakan. Atas dasar putusan MK ini, frasa yang sama yang terdapat dalam Pasal 250 huruf b PP No. 11 Tahun 2017 tentang Manajemen PNS harus dimaknai telah ditiadakan pula.
} 
250 huruf b dan huruf d, serta Pasal 251 PP No. 11 Tahun 2017 tentang Manajemen Pegawai Negeri Sipil, tidak diatur mekanisme dan prosedurnya.

Berdasarkan norma Hukum Administrasi, ketentuan tentang mekanisme dan prosedur pembuatan dan penerbitan keputusan itu, termasuk keputusan tentang pemberian sanksi, merupakan unsur penting. Hal ini karena terkait dengan keabsahan keputusan. Secara normatif, suatu keputusan itu keabsahan atau ketidakabsahannya diuji dan dinilai bukan saja terhadap isinya tetapi juga mekanisme dan prosedur pembuatan dan penerbitannya. ${ }^{2}$

SKB 3 Menteri tersebut menjadi pedoman (rechtslijn) bagi pejabat yang berwenang memberikan hukuman atau Pejabat Pembina Kepegawaian untuk mengeluarkan keputusan pemberhentian dengan hormat atau tidak dengan hormat bagi PNS yang melakukan tindak pidana, tanpa perlu melalui proses dan prosedur sebagaimana diatur dalam Pasal 23 sampai dengan Pasal 31 PP No. 53 Tahun 2010 tentang Disiplin PNS. Di samping itu, SKB 3 Menteri ini dikeluarkan dalam rangka sinergitas dan koordinasi Kementerian/Lembaga dalam rangka penegakan hukum khususnya terkait penjatuhan sanksi berupa pemberhentian tidak dengan hormat sebagai PNS, sebagaimana disebutkan dalam diktum kesatu SKB 3 Menteri.

Ketika Pejabat Pembina Kepegawaian menerbitkan keputusan, di dalam keputusan pemberhentian tersebut dicantumkan putusan pengadilan yang sudah memiliki kekuatan hukum tetap (in kracht van gewijsde). Putusan pengadilan yang telah memiliki kekuatan hukum tetap dijadikan sebagai dasar atau alasan pemberhentian PNS yang bersangkutan, dan putusan (vonnis) hakim itu ditempatkan dalam konsideran keputusan.

Uraian di atas menggambarkan adanya persoalan hukum, khususnya berkaitan dengan eksistensi dan keabsahan SKB 3 Menteri. Ada beberapa penelitian yang sebelumnya membahas mengenai SKB 3 Menteri tersebut. Beberapa penelitian tersebut diantaranya membahas mengenai kedudukan SKB 3 Menteri dalam hierarki

\footnotetext{
2 Berdasarkan Pasal 52 ayat (2) UU PTUN, suatu keputusan tata usaha negara dikualifikasi "bertentangan dengan peraturan perundang-undangan yang berlaku" yang meliputi tiga aspek; pertama, bertentangan dengan ketentuan-ketentuan dalam peraturan perundang-undangan yang bersifat prosedural/formal; kedua, bertentangan dengan ketentuan-ketentuan dalam peraturan perundang-undangan yang bersifat material/substansial; dan ketiga, dikeluarkan oleh Badan atau Pejabat Tata Usaha Negara yang tidak berwenang.
} 
peraturan perundang-undangan. ${ }^{3}$ Ada juga yang menilai SKB 3 Menteri ini sebagai langkah revitalisasi manajemen ASN melalui pemberhentian tidak dengan hormat bagi PNS yang terlibat tindak pidana korupsi. ${ }^{4}$ Namun demikian, penelitian sebelumnya belum secara spesifik dan fokus mengkaji kedudukan dan karakter hukum dari SKB 3 Menteri dalam konsepsi Hukum Administrasi, dan keabsahannya sebagai instrumen yuridis dalam manajemen kepegawaian atau penyelesaian hukum terhadap penerapan sanksi bagi ASN.

\section{Rumusan Masalah}

Berdasarkan uraian ringkas di atas, isu hukum yang akan dianalisis dalam penelitian ini adalah; Pertama, bagaimanakah kedudukan hukum (rechtspositie) dan karakter hukum (rechtskarakter) dari SKB 3 Menteri dalam perspektif Hukum Administrasi Negara?; Kedua, bagaimana keabsahan dan mekanisme pengujian SKB 3 Menteri sebagai instrumen yuridis dalam hukum administrasi negara?

\section{Tujuan Penelitian}

Tujuan dilakukannya penelitian ini adalah; Pertama, untuk menganalisis kedudukan hukum (rechtpositie) dan karakter hukum (rechhtskarakter) dari SKB 3 Menteri dimaksud dari perspektif Hukum Administrasi Negara; Kedua, untuk menganalisis keabsahan dan mekanisme pengujian SKB 3 Menteri sebagai instrumen yuridis dalam Hukum Administrasi Negara.

\section{Metode Penelitian}

Penelitian ini merupakan penelitian normatif yaitu penelitian terhadap kaidah atau hukumnya itu sendiri dan asas hukum positif, dengan menjadikan bahan-bahan hukum (sources of the law) sebagai objek kajian, khususnya SKB 3 Menteri. Metode pendekatan yang akan digunakan adalah pendekatan perundang-undangan (statute approach) dan pendekatan konseptual (conceptual approach). SKB 3 Menteri ini akan dianalisis secara normatif, yaitu dengan

3 Firzhal Arzhi Jiwantara, "Kedudukan Surat Keputusan Bersama (SKB) Menteri dan Badan Kepegawaian negara dalam Hierarki Peraturan perundang-undangan di Indonesia”, Jurnal Jatiswara, Vol. 34 No. 3 November 2019: 260-267.

${ }^{4}$ Nurmalita Ayuningtyas Harahap, "Revitalisasi Manajemen Aparatur Sipil Negara Melalui Pemberhentian Tidak Dengan Hormat Bagi Pegawai Negeri Sipil yang Terlibat Tindak Pidana Korupsi”, Jurnal Panorama Hukum, Vol. 3 No. 2 Desember 2018: 155-170. 
menggunakan norma Hukum Administrasi dan peraturan perundang-undangan yang berlaku.

\section{Hasil Penelitian dan Pembahasan}

Kedudukan Hukum (rechtspositie) dan Karakter Hukum (rechtskarakter) dari Surat Keputusan Bersama 3 Menteri

Di suatu negara hukum (rechtsstaat), pada dasarnya setiap tindakan atau keterlibatan pemerintah dalam kehidupan warga negara harus berdasarkan pada asas legalitas (legaliteitsbeginsel). Asas legalitas mengandung maksud bahwa penyelenggaraan pemerintahan harus berdasarkan pada peraturan perundangundangan yang berlaku atau didasarkan pada kewenangan yang bersumber pada undang-undang. Tindakan pemerintahan yang berdasarkan asas legalitas ini oleh karenanya berkonsekuensi pada tindakan tersebut sah (wetmatigheid van bestuur). Setiap tindakan kekuasaan pemerintah, menurut Sir William Wade, yaitu setiap tindakan yang memengaruhi hak, kewajiban atau kebebasan setiap orang, harus ditunjukkan dasar hukumnya secara tegas. ${ }^{5}$

Hanya saja, apabila mendasarkan setiap tindakan pemerintahan pada peraturan perundang-undangan juga bukan tanpa masalah. Hal ini karena, menurut Bagir Manan, adanya cacat bawaan (natural defect) dan cacat buatan (artificial defect) dari peraturan perundang-undangan sebagai suatu bentuk hukum tertulis. Sebagai ketentuan tertulis (written rule) atau hukum tertulis (written law) peraturan perundang-undangan mempunyai jangkauan yang terbatas - sekadar moment opname dari unsur-unsur politik, ekonomi, sosial, budaya, dan hankam yang paling berpengaruh pada saat pembentukan, karena itu mudah sekali aus (out of date) bila dibandingkan dengan perubahan masyarakat yang semakin cepat atau dipercepat. ${ }^{6}$

Peraturan perundang-undangan yang akan dijadikan dasar tindakan pemerintah dalam kondisi tertentu dapat saja belum tersedia atau memang tidak ada (leemten in het recht). Di sisi lain, dimungkinkan telah ada peraturan

${ }^{5}$ Sir William Wade dan Christhoper Forsyth, Administrative Law, Eighth Edition, Oxford University Press, New York, 2000, hlm. 20.

6 Bagir Manan dan Kuntana Magnar, Peranan Peraturan Perundang-undangan dalam Pembinaan Hukum Nasional, Armico, Bandung, 1987, hlm. 16. 
perundang-undangan yang dapat dijadikan dasar bagi pemerintah untuk melakukan tindakan-tindakan hukum (rechtshandelingen) tetapi memuat norma yang samar (vage norm) atau norma terbuka (open texture), dan dimungkinkan pula normanya mengandung pilihan (choice). Norma kabur (vage norm) adalah norma yang pengertiannya tidak dapat ditetapkan secara persis, sehingga lingkupnya tidak jelas, sedangkan norma terbuka (open texture) adalah norma yang pengertian-pengertiannya memuat ciri-ciri yang dalam perjalanan waktu mengalami perubahan. ${ }^{7}$ Dengan kata lain, norma terbuka merupakan norma yang terbuka substansi atau isinya dan harus ditentukan lebih lanjut dalam pelbagai keadaan atau norma yang isinya tidak dapat ditentukan secara abstrak tetapi sangat bergantung pada keadaan kasus di mana norma tersebut diterapkan. ${ }^{8}$

Suatu keadaan di atas memicu pemberian diskresi kepada pemerintah. Diskresi atau Ermessen yaitu kebebasan untuk mengambil kebijakan (beleidsvrijheid), menjelaskan norma undang-undang yang samar (uitleg van wettelijke voorschriften), menentukan fakta-fakta (vaststelling van feiten), melakukan interpretasi (interpretatieurijheid), mengambil pilihan, dan mempertimbangkan (beoordelingsvrijheid) berbagai kepentingan terkait dalam penyelenggaraan urusan pemerintahan atau pelayanan publik. ${ }^{9}$ Florence Heffron dan Neil McFeeley mengatakan:

"Discretion, then, is the leeway an administrator has, because of the imprecise nature of authorizing statutes or ragulation, to make individual decisions on interpretation, application, and/or enforcement of the law. Discretion is not only necessity, but is beneficial in a society that believe in the concept of "individualized justice". Without discretion laws could not deal equitably with the unique facts and circumstances presented by specific case: It could not treat unequals unequally". 10

(Dengan demikian, diskresi merupakan peluang bagi pemerintah, karena kesamaran alami undang-undang atau peraturan yang memberikan wewenang, untuk membuat keputusan secara individual berdasarkan interpretasi, implementasi, dan/atau penegakan hukum. Diskresi bukan hanya perlu, tetapi juga bermanfaat dalam suatu masyarakat yang mempercayai konsep "keadilan orang perorang atau merata". Tanpa diskresi

${ }^{7}$ J.J.H. Bruggink, Renfleksi tentang Hukum, Alih Bahasa B. Arief Sidarta, Citra Aditya Bakti, Bandung, 1996, hlm. 61 dan 68 .

8 Dyah Octarina Susanti dan A'an Efendi, "Memahami Teks Undang-Undang dengan Metode Interpretasi Eksegetikal”, Jurnal Kertha Patrika, Vol. 41, No. 2 Agustus 2019, hlm. 147.

${ }_{9}^{9}$ F.C.M.A. Michiels (red.), Staats-en Bestuursrecht Tekst en Materiaal, Tweede Druk, Kluwer, Deventer, 2004, hlm. 139-140.

${ }^{10}$ Florence Heffron dan Neil McFeeley, The Administrative Regulatory Process, Longman, New York, 1983, hlm. 44. 
hukum tidak dapat diterapkan secara wajar terhadap fakta-fakta yang spesifik dan kondisi yang ditampilkan kasus tertentu: fakta yang tidak sama tidak dapat diperlakukan secara sama).

Adanya norma terbuka dan norma samar itu sebenarnya sesuai dengan dinamikan kemasyarakat dan fungsi pemerintahan. Norma samar akan memberikan keleluasaan pengemban kewenangan untuk menyesuaikan berlakunya norma hukum positif dalam masyarakat, akan bersifat fleksibel dalam situasi dan kondisi dimana norma hukum positif tersebut berlaku. ${ }^{11}$

Berdasarkan Pasal 22 ayat (2) UU No. 30 Tahun 2014 tentang Administrasi Pemerintahan (UUAP), diskresi itu ditujukan untuk; a) melancarkan penyelenggaraan pemerintahan; b) mengisi kekosongan hukum; c) memberikan kepastian hukum; dan d) mengatasi stagnasi pemerintahan dalam keadaan tertentu guna kemanfaatan dan kepentingan umum. Diskresi diperlukan dalam hukum administrasi dalam rangka menyelesaikan persoalan yang peraturan perundang-undangan belum mengaturnya atau mengatur secara umum, sehingga administrasi negara mempunyai kebebasan untuk menyelesaikan atas inisiatif sendiri. ${ }^{12}$ Diskresi merupakan kebebasan dalam mengambil keputusan atau tindakan dalam situasi khusus (in a particular situation). ${ }^{13}$

Ketika diskresi itu dituangkan alam bentuk tertulis (naar buiten gebracht schricftelijk beleid), maka diskresi itu menjadi peraturan kebijakan (beleidsregel). Peraturan kebijakan adalah peraturan umum yang dikeluarkan oleh instansi pemerintahan berkenaan dengan pelaksanaan wewenang pemerintahan terhadap warga negara atau terhadap instansi pemerintahan lainnya dan pembuatan peraturan tersebut tidak memiliki dasar yang tegas dalam UUD dan undangundang formal baik langsung maupun tidak langsung. Artinya peraturan kebijakan tidak didasarkan pada kewenangan pembuatan undang-undang - oleh karena itu tidak termasuk peraturan perundang-undangan yang mengikat umum - tetapi dilekatkan pada wewenang pemerintahan dari suatu organ administrasi

\footnotetext{
11 Abintoro Prakoso, "Vage Normen sebagai Sumber Hukum Diskresi yang Belum Diterapkan oleh Polisi Penyidik Anak", Jurnal Hukum Ius Quia Iustum, Nomor 2 Vol. 17 April 2010, hlm. 254.

12 Arfan Faiz Muhlizi, "Reformulasi Diskresi dalam Penataan Hukum Administrasi”, Jurnal Rechtsvinding Vol. 1 Nomor 1 Januari - April 2012, hlm. 108.

13 Eva Thomann, et.al., "The Necessity of Discretion: A Behavioral Evalution of Bottom-Up Implementation Theory", Journal of Public Administration Research and Theory, Vol. 28, 3 Juli 2018, hlm. 583.
} 
dan terkait dengan pelaksanaan kewenangannya. ${ }^{14}$ Atas dasar pengertian ini, SKB itu pada dasarnya adalah peraturan kebijakan, yaitu peraturan yang dibuat atas dasar diskresi atau Ermessen. SKB itu bukan dan tidak dapat dikualifikasi sebagai peraturan perundang-undangan.

H.D. van Wijk/Willem Konijnenbelt menyebutkan bahwa peraturan kebijakan itu secara esensial berkenaan dengan; pertama, organ pemerintahan dalam hal ini semata-mata menggunakan wewenang untuk menjalankan tindakan-tindakan pemerintahan; kedua, wewenang pemerintahan itu tidak terikat secara tegas; ketiga, memuat ketentuan umum dan digunakan untuk melaksanakan wewenang. ${ }^{15}$ Peraturan kebijakan (beleidsregel) adalah sarana hukum (juridische instrumentarium) tata usaha negara yang bertujuan mendinamisir keberlakuan peraturan perundangundangan (algemene verbindende voorschrift). ${ }^{16}$

SKB 3 Menteri tersebut di atas merupakan peraturan kebijakan yang dikeluarkan karena ketiadaaan peraturan perundang-undangan (geen wettelijke voorschriften bestaan atau leemten in het recht) yang mengatur tentang pemberhentian dengan hormat atau tidak dengan hormat terhadap PNS yang melakukan tindak pidana. Keberadaan SKB 3 Menteri tersebut ditujukan untuk mengisi kekosongan hukum, khususnya aturan prosedural penjatuhan sanksi bagi pegawai negeri yang dijatuhi hukuman berdasarkan putusan pengadilan yang berkekuatan hukum tetap karena melakukan tindak pidana kejahatan jabatan atau tindak pidana kejahatan yang ada hubungannya dengan jabatan.

Berdasarkan keterangan di atas, tampak bahwa mekanisme dan prosedur pembuatan dan penerbitan keputusan penjatuhan sanksi atau hukuman terhadap PNS yang melanggar Peraturan Disiplin itu telah diatur dengan peraturan perundang-undangan yaitu Pasal 23 sampai dengan Pasal 31 PP No. 53 Tahun 2010 tentang Disiplin PNS. Sedangkan penerbitan keputusan penjatuhan sanksi terhadap PNS karena melakukan tindak pidana itu berpedoman pada SKB, yang bukan peraturan perundang-undangan (regeling) tetapi peraturan kebijakan (beleidsregel).

\footnotetext{
14 P.J.P Tak, Rechtsvorming in Nederland, Samsom H.D. Tjeenk Willink, 1991, hlm. 129.

15 H.D. van Wijk/Willem Konijnenbelt, Hoofdstukeen van Administratief Recht, Uitgeverij Lemma BV. Utrecht. 1995, hlm. 271.

${ }^{16}$ Laica Marzuki, "Peraturan Kebijaksanaan (Beleidsregel) Hakikat serta Fungsinya Selaku Sarana Hukum Pemerintahan", Makalah pada Penataran Nasional Hukum Acara dan Hukum Administrasi Negara, Fakultas Hukum Universitas Hasanudin, Ujung Pandang, 26-31 Agustus 1996, hlm. 9.
} 
Perlu ditegaskan bahwa sebagai peraturan kebijakan, SKB 3 Menteri itu sendiri bukan dan tidak dapat dijadikan dasar hukum penerapan hukuman. Dasar hukum untuk pengenaan hukuman bagi PNS itu ada pada peraturan perundang-undangan yaitu UU No. 5 Tahun 2014 tentang ASN dan PP No. 11 Tahun 2017 tentang Manajemen PNS. Adapun SKB 3 Menteri ini hanyalah pedoman penjatuhan sanksi terhadap PNS karena melakukan tindak pidana kejahatan jabatan atau tindak pidana kejahatan yang ada hubungannya dengan jabatan.

SKB 3 Menteri ini tidak memuat sanksi pidana, dan memang secara keilmuan hukum tidak boleh memuat sanksi pidana. Isi SKB 3 Menteri ini hanya berkenaan dengan tata cara penjatuhan sanksi bagi PNS yang telah dijatuhi hukuman berdasarkan putusan pengadilan yang telah memiliki kekuatan hukum tetap. Selain itu juga terdapat pedoman pemberian sanksi bagi Pejabat Pembina Kepegawaian yang tidak melaksanakan penjatuhan sanksi bagi PNS, peningkatan sistem informasi kepegawaian, optimalisasi pengawasan dan peningkatan peran Aparat Pengawas Internal Pemerintah, dan monitoring pelaksanaan Keputusan Bersama secara terpadu.

Sebenarnya agar penerbitan keputusan penjatuhan sanksi terhadap PNS karena melakukan tindak pidana itu didasarkan pada peraturan perundang-undangan (asas legalitas), caranya cukup dengan menambah satu pasal atau ayat dalam UU No. 5 Tahun 2014 dan PP No. 11 Tahun 2017, yang berisi pemberian wewenang beserta prosedur singkat penerbitan keputusan. Hanya saja, menambah pasal atau ayat dalam peraturan perundang-undangan itu sama artinya dengan melakukan perubahan terhadap peraturan perundang-undangan tersebut. Hal ini dalam praktiknya bukan urusan sederhana karena menyangkut banyak aspek seperti kesiapan dan kemauan pembuat undang-undang, penganggaran atau pembiayaan, ketersediaan waktu, dan sebagainya. Hal ini berbeda jika perubahan itu hanya terkait dengan peraturan pelaksanaan undang-undang yang dapat dilakukan secara langsung oleh pembuat peraturan pelaksanaan. SKB 3 Menteri oleh karenanya dapat terus diberlakukan sampai ada perubahan undang-undang untuk alasan efektivitas dan efisiensi (doeltreffenheid dan doelmatigheid).

SKB 3 Menteri sebagai suatu peraturan kebijakan (beleidsregel), seperti halnya peraturan perundang-undangan (regeling), mulai berlaku sejak tanggal penetapan. Sesuai dengan tanggal yang tertera di bagian akhir SKB tersebut, SKB Menteri Dalam 
Negeri, Menteri Pendayagunaan Aparatur Negara dan Reformasi Birokrasi, dan Kepala Badan Kepegawaian Negara mulai berlaku pada 13 September 2018.

Sehubungan dengan SKB 3 Menteri ini diterbitkan dengan tujuan yang spesifik sebagai pedoman bagi pejabat yang berwenang memberikan hukuman atau Pejabat Pembina Kepegawaian untuk mengeluarkan keputusan pemberhentian dengan hormat atau tidak dengan hormat bagi PNS yang melakukan tindak pidana, maka pemberlakuannya harus pula dikaitkan dengan ketentuan Pasal 252 PP No. 11 Tahun 2017. Pasal 252 PP No. 11 Tahun 2017 menentukan bahwa, "Pemberhentian sebagaimana dimaksud dalam Pasal 250 huruf b dan huruf d dan Pasal 251 ditetapkan terhitung mulai akhir bulan sejak putusan pengadilan atas perkaranya yang telah memiliki kekuatan hukum tetap". Artinya semua putusan (vonnis) yang telah memiliki kekuatan hukum tetap (in kracht van gewijsde) yang dikeluarkan sejak 13 September 2018 dan seterusnya akan dijadikan dasar dikeluarkannya keputusan (beschikking) untuk pemberhentian dengan hormat atau tidak dengan hormat bagi PNS yang melakukan tindak pidana kejahatan jabatan atau tindak pidana kejahatan yang ada hubungannya dengan jabatan.

Keputusan pemberhentian dengan hormat atau tidak dengan hormat bagi PNS yang melakukan tindak pidana kejahatan jabatan atau tindak pidana kejahatan yang ada hubungannya dengan jabatan sebelum 13 September 2018, tidak dapat berpedoman pada SKB tersebut. Dengan kata lain, SKB tersebut beserta turunannya apakah Surat Edaran (circulair), petunjuk pelaksanaan (Juklak), Petunjuk Teknis (Juknis), keputusan, ataupun lainnya, tidak dapat diberlakukan mundur (terugwerkend).

Pemberlakuan mundur SKB 3 Menteri tersebut akan menimbulkan beberapa masalah hukum; pertama, bertentangan dengan asas kepastian hukum (rechtszekerheid) yang merupakan salah satu asas dalam AUPB. Berdasarkan UU PTUN dan UUAP, telah jelas bahwa parameter keabsahan tindakan pemerintahan itu adalah peraturan perundang-undangan dan Asas-asas Umum Pemerintahan yang Baik (AUPB). Artinya suatu tindakan pemerintahan itu akan dikualifikasi tidak sah (onrechtmatig) jika bertentangan dengan peraturan perundangundangan dan/atau AUPB; kedua, dengan pemberlakuan mundur itu berarti ada 
keputusan pemberhentian dengan hormat atau tidak dengan hormat bagi PNS yang melakukan tindak pidana kejahatan jabatan atau tindak pidana kejahatan yang ada hubungannya dengan jabatan sebelum 13 September 2018.

Keputusan yang diberlakukan surut (terugzerkend) atau pencantuman tanggal mundur (backdated), tidak dapat diterapkan terhadap keputusan yang bersifat konstitutif (beschikking rechtsscheppend). Keputusan konstitutif dimaksud yakni keputusan yang menimbulkan atau meniadakan hak dan kewajiban yang ada dan berlaku bagi penerima keputusan. Pencantuman tanggal mundur atau pemberlakuan surut, hanya dapat dilakukan terhadap keputusan yang sifatnya deklaratoir (beschikking rechtsvastellend). Keputusan deklaratoir yaitu keputusankeputusan yang tidak menimbulkan atau meniadakan hak dan kewajiban yang ada dan berlaku bagi penerima keputusan. Keputusan konstitutif yang diberlakukan mundur atau dibuat tanggal mundur akan menyebabkan keputusan itu mengandung cacat hukum (rechtsgebreken), yang menyebabkan keputusan tersebut tidak memiliki kekuatan hukum (rechtskracht) untuk diberlakukan.

Berdasarkan Pasal 57 UUAP disebutkan bahwa "Keputusan berlaku pada tanggal ditetapkan, kecuali ditentukan lain dalam Keputusan atau ketentuan peraturan perundang-undangan yang menjadi dasar Keputusan" dan dalam Pasal 58 ayat (6) UU ini ditentukan bahwa "Keputusan tidak dapat berlaku surut, kecuali untuk menghindari kerugian yang lebih besar dan/atau terabaikannya hak Warga Masyarakat"; ketiga, pencantuman tanggal mundur atau pemberlakuan surut keputusan pemberhentian dengan hormat atau tidak dengan hormat bagi PNS yang melakukan tindak pidana kejahatan jabatan atau tindak pidana kejahatan yang ada hubungannya dengan jabatan, sama artinya dengan berpedoman atau mendasarkan pada pedoman (rechtslijn) yang tidak atau belum ada. Hal ini tergolong sebagai "aperte onredelijkheid" yaitu nyata-nyata tidak masuk akal atau irrationality dalam penerbitan keputusan.

Berdasarkan doktrin Hukum Administrasi, keputusan yang dibuat dengan "aperte onredelijkheid" atau "irrationality", 17 itu dikualifikasi mengandung unsur sewenang-wenang (willekeur) dan harus dianggap tidak sah (onrechtmatig) karena melanggar asas larangan bertindak sewenang-wenang (verbod van willekeur

\footnotetext{
${ }^{17}$ Keputusan yang tidak rasional atau tidak masuk akal.
} 
beginsel) dalam AUPB. ${ }^{18}$ Philipus M. Hadjon memberikan contoh tindakan tidak masuk akal atau sewenang-wenang sebagai berikut:

"Misalnya ketentuan untuk melampirkan surat keterangan kesehatan bagi pemohon pensiun hari tua. Ketentuan semacam itu jelas bertentangan dengan peraturan yang berlaku karena tidak ada ketentuan yang mengharuskan itu. Di sisi lain ketentuan itu dapat diukur dengan segi kewajaran, akal sehat serta keharusan untuk memutus atas informasi yang lengkap (asas motivering). Dengan ukuran ini jelas bahwa adalah sangat tidak masuk akal untuk mewajibkan pemohon pensiun hari tua untuk melampirkan keterangan kesehatan, karena keterangan sehat atau tidak sehat untuk apa? Apakah perlu keterangan yang isinya: sehat untuk pensiun?". ${ }^{19}$

Aturan-aturan atau syarat-syarat tambahan yang sebenarnya tidak diperlukan acapkali ditemukan dalam penyelenggaraan pemerintahan. Misalnya untuk mendapatkan pelayanan administrasi tertentu, disamping harus menunjukkan KTP juga harus melampirkan kartu keluarga, akta kelahiran, ijazah, dan sebagainya.

\section{Keabsahan dan Mekanisme Pengujian Surat Keputusan Bersama 3 Menteri sebagai Instrumen Yuridis Hukum Administrasi Negara}

SKB sebagai suatu peraturan kebijakan atau peraturan yang lahir atas dasar diskresi, bukan atas dasar kewenangan pembuatan peraturan perundangundangan bagi organ pemerintah (delegatie van regelgevende bevoegdheid aan bestuursorganen). SKB sebagaimana peraturan kebijakan lainnya, merupakan instrumen yuridis yang diperlukan dalam penyelenggaraan urusan pemerintahan, di samping peraturan perundang-undangan. Diskresi dan peraturan kebijakan merupakan kekuasaan dan instrumen penyelenggaraan pemerintahan yang sangat diperlukan bahkan disebutkan "discretion is at heart of agency power". ${ }^{20}$ Diskresi dan peraturan kebijakan dibutuhkan untuk terselenggaranya tugas-tugas pemerintahan terutama dalam rangka memberikan pelayanan terhadap warga negara secara efektif (doeltreffenheid) dan efisien (doelmatigheid).

Diskresi dan peraturan kebijakan itu memang sangat diperlukan dalam penyelenggaraan pemerintahan, namun karena di dalamnya mengandung unsur

${ }^{18}$ Indroharto, Asas-asas Umum Pemerintahan yang Baik, tulisan pada Buku Paulus Effendie Lotulung (Eds), Himpunan Makalah Asas-asas Umum Pemerintahan yang Baik, Citra Aditya Bakti, Bandung, 1994, hlm. 166. Lihat pula D.J. Galligan, Discretionary Power, Oxford Press University, New York, 1990, hlm. 143.

19 Philipus M. Hadjon, vide Paulus E. Lotulung, Ibid., hlm. 116.

${ }^{20}$ Bernard Schwartz, Administrative Law, Little Brown and Company, Boston, 1991, hlm. 652. 
kebebasan pejabat pemerintah untuk mengambil kebijakan (beleidsvrijheid), maka perlu ada rambu-rambu atau norma-norma dalam pembuatan dan penggunaannya. Berkenaan dengan hal ini, Bagir Manan mengatakan:

"Perlu ditiadakan kesan, seolah-olah peraturan kebijakan atas dasar freies Ermessen atau beleidsvrijheid adalah peraturan yang semata-mata berkaitan dengan doelmatigheid sehingga tidak terkait dengan unsur rechtmatigheid, bahkan dapat menyimpangi rechtmatigheid. Kesan semacam ini tidak benar (keliru). Unsur doelmatigheid sebagai alas freies Ermessen haruslah suatu tujuan atau manfaat yang dibenarkan hukum. Kebebasan bertindak adalah kebebasan dalam lingkup wewenang yang telah ditentukan berdasarkan hukum. Setiap tindakan administrasi negara di luar wewenang yang telah ditetapkan berdasarkan hukum, termasuk tindakan berdasarkan freies Ermessen adalah tindakan melampaui wewenang (detournement de pouvoir), bahkan dapat melawan hukum (onrechtmatige overheidsdaad), atau penyalahgunaan wewenang (misbruik van recht)". ${ }^{21}$

Penggunaan diskresi dan pembuatan peraturan kebijakan harus memerhatikan ketentuan yang berupa legalitas (legality). Legalitas dalam arti tidak bertentangan dengan asas dan hukum yang berlaku dan harus dilaksanakan dalam lingkungan formil wewenangnya (binnen formele kring van zijn bevoegdheid), yaitu hanya dapat dikeluarkan oleh pejabat yang berwenang.

Penggunaan diskresi dan pembuatan peraturan kebijakan harus juga didasarkan pada asas rasionalitas (rationality atau redelijkheid beginsel) yang meliputi pertimbangan yang relevan (relevant consideration), kejujuran dan keterbukaan (fairness), tujuan yang layak (proper purpuse), serta konsistensi (consistency) dalam arti alasan untuk suatu tindakan itu sesuai satu sama lain.

Penggunaan diskresi yang menjadi dasar pembuatan dan penerbitan peraturan kebijakan, berdasarkan Pasal 24 UUAP harus memenuhi syarat-syarat sebagai berikut:22

a. sesuai dengan tujuan Diskresi sebagaimana dimaksud dalam Pasal 22 ayat (2);

b. tidak bertentangan dengan ketentuan peraturan perundang-undangan;

c. sesuai dengan AUPB;

d. berdasarkan alasan-alasan yang objektif;

${ }^{21}$ Bagir Manan, Teori dan Politik Konstitusi, FH UII Press, Yogyakarta, 2003, hlm. 16.

22 Ketentuan ini telah diubah dengan Undang-Undang Nomor 11 Tahun 2020 tentang Cipta Kerja. Sebagaimana Pasal 24 UUAP yang tercantum dalam Pasal 175 angka 2 UU Cipta Kerja, ditentukan bahwa Pejabat Pemerintah yang menggunakan Diskresi harus memenubi syarat: a. sesuai dengan tujuan Diskresi sebagaimana dimaksud dalam Pasal 22 ayat (2); b. sesuai dengan AUPB; c. berdasarkan alasan-alasan yang objektif; d. tidak menimbulkan Konflik. Kepentingan; dan e. dilakukan dengan iktikad baik. 
e. tidak menimbulkan Konflik Kepentingan; dan

f. dilakukan dengan iktikad baik.

Telah dikemukakan bahwa SKB itu tergolong peraturan kebijakan (beleidsregel), bukan peraturan perundang-undangan (regeling). Oleh karena itu, asas-asas pembatasan dan pengujian terhadap peraturan perundang-undangan tidak dapat diberlakukan pada peraturan kebijakan. Selain itu, peraturan kebijakan juga tidak dapat diuji secara wetmatigheid, karena memang tidak ada dasar peraturan perundang-undangan untuk membuat keputusan peraturan kebijakan tersebut. ${ }^{23}$

Sehubungan bahwa SKB 3 Menteri itu merupakan peraturan kebijakan, mengajukan judicial review ke Mahkamah Agung (MA) itu tidak dapat dilakukan. Hal ini karena telah jelas bahwa berdasarkan Pasal 31 ayat (1) UU No. 14 Tahun 1985 tentang Mahkamah Agung, sebagaimana telah diubah terakhir dengan UU No. 3 Tahun 2009 tentang Perubahan Kedua Atas UU No. 14 Tahun 1985 tentang Mahkamah Agung, kewenangan MA itu menguji peraturan perundangundangan (regeling) di bawah undang-undang. Mahkamah Agung tidak berwenang menguji peraturan kebijakan.

Mahkamah Agung atau lembaga peradilan tidak diberikan kewenangan untuk memeriksa dan menguji peraturan kebijakan itu didasarkan pada adagium "de rechter mag niet op de stoel van de administratie gaan zitten", 24 (hakim tidak boleh duduk di kursi pemerintah). Adagium ini didasarkan pada pemikiran separation of power atau machtenscheiding dalam suatu negara hukum, yang menghendaki independensi antar organ-organ kenegaraan (staatsorganen). F.H. van Der Burg dan kawan-kawan menyatakan; "Daarmede werd uitgedrukt dat de rechter wanneer hij een oordeel geeft over de aan hem voorgelegde besluiten en handelingen van bestuurlijke overheden, de beleidsvrijheid van het bestuur moet respecteren. De rechter mag niet de belangenafweging van de bestuurlijke autoriteiten gaan overdoen", 25 (dengan ungkapan itu dinyatakan bahwa hakim ketika ia memberikan pertimbangan terhadap keputusan dan tindakan administratif pemerintah yang diajukan

${ }^{23}$ Bagir Manan, "Peraturan Kebijaksanaan”, Makalah, Jakarta, 1994, hlm. 16. hlm. 109.

${ }^{24}$ A.D. Belinfante, Kort Begrip van het Administratief Recht, Samsom Uitgeverij, Alphen aan den Rijn, 1985,

${ }^{25}$ F.H. van Der Burg, et.al., Rechtshescherming tegen de Overheid, Nijmegen, 1985, hlm. 158. 
kepadanya, harus menghormati kebijakan pemerintah. Hakim tidak boleh menilai pertimbangan kepentingan kekuasaan administrasi). Menurut Sudargo Gautama:

"Jika hakim turut campur dengan leluasa dalam kebijakan pemerintah, maka politik sang hakim akan menjadi politik pemerintah, kebijakan hakim akan merupakan kebijakan pemerintah. Teranglah dalam praktik hal ini tak dapat terlaksana dengan baik. Kita hanya ingat kepada kurang pengalaman-praktik (practijkervaring) dari hakim untuk mengetahui segala seluk beluk yang berhubungan dengan kebijakan itu supaya berjalan dengan lancar sesuai dengan kepentingan umum yang sebenarnya" ${ }^{26}$

Dewasa ini pendapat bahwa diskresi dan peraturan kebijakan itu tidak dapat diuji dan dinilai oleh hakim, agaknya sudah mulai dipertanyakan. Philipus M. Hadjon mengemukakan bahwa "kekuasaan bebas (discretionary power, discretionaire bevoegdheid) yang semula seakan-akan tidak terjamah oleh "rechtsmatigheidstoetsing" sudah lama ditinggalkan".27

Diskresi dan peraturan kebijakan sebenarnya merupakan kewenangan, yaitu kewenangan bebas (vrij bevoegdheid), sebagai lawan dari kewenangan terikat (gebonden bervoegdheid). Sebagai suatu kewenangan, tentu sama dengan kewenangan pemerintahan lainnya yakni dilekatkan pada jabatan verbonden aan het $a m b t,{ }^{28}$ dan dijalankan oleh pejabat (ambtsdrager). Meskipun diskresi itu merupakan kewenangan bebas, namun bukan dalam arti semaunya atau sesukanya digunakan. Penggunaan diskresi itu selain harus memerhatikan norma dan ketentuan yang telah disebutkan di atas, termasuk harus dengan iktikad baik seperti disebutkan dalam Pasal 24 UUAP.

Penggunaan diskresi dan peraturan kebijakan juga tidak boleh digunakan sewenang-wenang dan menyalahgunakan wewenang, harus masuk akal, dan memerhatikan asas persamaan, asas kepastian hukum, asas kecermatan, dan lainlain. ${ }^{29}$ Di samping itu, sebagai suatu kewenangan, c.q. vrij bevoegdheid, berlaku asas "geen bevoegdheid zonder verantwoordelijkheid dan geen verantwoordelijkheid zonder verantwoording" (tidak ada kewenangan tanpa pertanggungjawaban dan tidak ada pertanggungjawaban tanpa kewajiban), yang dapat dituntut melalui

\footnotetext{
${ }^{26}$ Sudargo Gautama, Pengertian tentang Negara Hukum, Alumni, Bandung, 1983, hlm. 67.

${ }^{27}$ Dalam Paulus Effendie Lotulung (Eds), Op. Cit., hlm. 105.

${ }_{28}$ F.A.M. Stroink en J.G. Steenbeek, Inleiding in het Staats-en Administratief Recht, Samsom H.D Tjeenk Willing, Alphen aan den Rijn, 1985, hlm. 36.

${ }^{29}$ P. de Haan, et.al., Bestuursrecht in de Sociale Rechsstaat. Deel 2, Kluwer-Deventer, 1986, hlm. 9.
} 
proses upaya administratif dan peradilan administrasi. Dengan bersandar pada asas ini, pejabat pemerintahan tidak dapat mengelak dari tanggung jawab ketika kewenangan yang digunakannya itu menimbulkan kerugian bagi warga negara.

Berdasarkan ketentuan yang berlaku sekarang ini dan adanya perluasan objek sengketa melalui UUAP, terlepas dari beberapa problem hukum di dalamnya dan prosedur upaya administratif yang belum ideal, SKB 3 Menteri dan instrumen hukum sejenisnya dapat diuji. Pengujian SKB 3 Menteri dan instrumen hukum sejenisnya dapat dilakukan melalui Peradilan Administrasi atas dasar Pasal 87 UUAP dan Peraturan Mahkamah Agung No. 2 Tahun 2019 tentang Pedoman Penyelesaian Sengketa Tindakan Pemerintahan dan Kewenangan Mengadili Perbuatan Melanggar Hukum oleh Badan dan/atau Pejabat Pemerintahan (onrechtmatige overheidsdaad). Dasar pengujian (toetsingsgrond) untuk menguji dan menilai keputusan dan/atau tindakan pemerintahan tidak mengalami perubahan atau penambahan yakni tetap menggunakan peraturan perundang-undangan dan AUPB, meskipun ada perluasan objek sengketa di Peradilan Administrasi.

SKB 3 Menteri tersebut jika diuji dengan peraturan perundang-undangan dan AUPB, tampak tidak bertentangan karena; pertama, dibuat dan dikeluarkan oleh pejabat yang memiliki kewenangan di bidang ASN yaitu Menteri Dalam Negeri, Menteri Pendayagunaan Aparatur Negara dan Reformasi Birokrasi, dan Kepala Badan Kepegawaian Negara; kedua, isi SKB 3 Menteri ini hanyalah pedoman (rechtslijn) penjatuhan sanksi terhadap PNS karena melakukan tindak pidana kejahatan jabatan atau tindak pidana kejahatan yang ada hubungannya dengan jabatan atas dasar putusan pengadilan yang sudah memiliki kekuatan hukum tetap (in kracht van gewijsde). SKB 3 Menteri ini tidak memuat sanksi pidana; ketiga, dalam SKB 3 Menteri ini tidak ditemukan adanya pelanggaran terhadap AUPB. Meskipun demikian, SKB 3 Menteri ini akan dikualifikasi tidak sesuai dengan asas hukum, bertentangan dengan peraturan perundangundangan, dan AUPB, jika diberlakukan mundur (terugwerkend).

\section{Penutup}

Berdasarkan hasil penelitian dan pembahasan di atas, penelitian ini menyimpulkan; pertama, SKB 3 Menteri ini merupakan peraturan kebijakan yang 
dikeluarkan sebagai pedoman bagi Pejabat Pembina Kepegawaian karena ketiadaaan peraturan perundang-undangan yang mengatur tentang pemberhentian dengan hormat atau tidak dengan hormat terhadap PNS yang melakukan tindak pidana kejahatan jabatan atau tindak pidana kejahatan yang ada hubungannya dengan jabatan berdasarkan putusan pengadilan yang berkekuatan hukum tetap. Kedua, SKB 3 Menteri itu dapat dikualifikasi sebagai instrumen yuridis yang sah (rechtmatig), kecuali jika diberlakukan mundur (terugwerkend). SKB 3 Menteri sebagai peraturan kebijakan dapat dilakukan pengujian melalui Peradilan Administrasi berdasarkan Pasal 87 UUAP, terlepas dari beberapa problem hukum di dalamnya dan prosedur upaya administratif yang belum ideal.

\section{Daftar Pustaka}

\section{Buku}

Belinfante, A.D., Kort Begrip van het Administratief Recht, Samsom Uitgeverij, Alphen aan den Rijn, 1985.

Bruggink, J.J.H., Renfleksi tentang Hukum, Alih Bahasa B. Arief Sidarta, Citra Aditya Bakti, Bandung, 1996.

Effendie Lotulung, Paulus (Eds), Himpunan Makalah Asas-asas Umum Pemerintahan yang Baik, Citra Aditya Bakti, Bandung, 1994.

Galligan, D.J., Discretionary Power, Oxford Press University, New York, 1990.

Gautama, Sudargo, Pengertian tentang Negara Hukum, Alumni, Bandung, 1983.

Haan, P. de, et.al., Bestuursrecht in de Sociale Rechsstaat. Deel 2, Kluwer-Deventer, 1986.

Heffron, Florence dan Neil McFeeley, The Administrative Regulatory Process, Longman, New York, 1983.

Manan, Bagir, Teori dan Politik Konstitusi, FH UII Press, Yogyakarta, 2003.

dan Kuntana Magnar, Peranan Peraturan Perundang-undangan dalam Pembinaan Hukum Nasional, Armico, Bandung, 1987.

Michiels, F.C.M.A. (red.), Staats-en Bestuursrecht Tekst en Materiaal, Tweede Druk, Kluwer, Deventer, 2004.

Schwartz, Bernard, Administrative Law, Little Brown and Company, Boston, 1991.

Stroink, F.A.M. en J.G. Steenbeek, Inleiding in het Staats-en Administratief Recht, Samsom H.D Tjeenk Willing, Alphen aan den Rijn, 1985.

Tak, P.J.P, Rechtsvorming in Nederland, Samsom H.D. Tjeenk Willink, 1991.

van Der Burg, F.H., et.al., Rechtsbescherming tegen de Overheid, Nijmegen, 1985. 
van Wijk/Willem Konijnenbelt, H.D., Hoofdstukken van Administratief Recht, Uitgeverij Lemma BV., Utrecht, 1995.

William Wade, Sir dan Christhoper Forsyth, Administrative Law, Eighth Edition, Oxford University Press, New York, 2000.

\section{Jurnal}

Abintoro Prakoso, "Vage Normen sebagai Sumber Hukum Diskresi yang Belum Diterapkan oleh Polisi Penyidik Anak", Jurnal Hukum Ius Quia Iustum Nomor 2 Vol. 17 April 2010.

Arfan Faiz Muhlizi, "Reformulasi Diskresi dalam Penataan Hukum Administrasi", Jurnal Rechtsvinding Vol. 1 Nomor 1 Januari - April 2012.

Dyah Octarina Susanti dan A'an Efendi, "Memahami Teks Undang-undang dengan Metode Interpretasi Eksegetikal", Jurnal Kertha Patrika, Vol. 41, No. 2 Agustus 2019.

Eva Thomann, et.al., "The Necessity of Discretion: A Behavioral Evalution of Bottom-Up Implementation Theory", Journal of Public Administration Research and Theory, Vol. 28, 3 Juli 2018.

Firzhal Arzhi Jiwantara, "Kedudukan Surat Keputusan Bersama (SKB) Menteri dan Badan Kepegawaian negara dalam Hierarki Peraturan perundangundangan di Indonesia", Jurnal Jatiswara, Vol. 34 No. 3 November 2019: 260-267.

Nurmalita Ayuningtyas Harahap, "Revitalisasi Manajemen Aparatur Sipil Negara Melalui Pemberhentian Tidak Dengan Hormat Bagi Pegawai Negeri Sipil yang Terlibat Tindak Pidana Korupsi", Jurnal Panorama Hukum, Vol. 3 No. 2 Desember 2018.

\section{Makalah}

Bagir Manan, “Peraturan Kebijaksanaan”, Makalah, Jakarta, 1994.

Laica Marzuki, "Peraturan Kebijaksanaan (Beleidsregel) Hakikat serta Fungsinya Selaku Sarana Hukum Pemerintahan", Makalah pada Penataran Nasional Hukum Acara dan Hukum Administrasi Negara, Fakultas Hukum Universitas Hasanudin, Ujung Pandang, 26-31 Agustus 1996.

\section{Peraturan Perundang-undangan}

Undang-Undang Nomor 14 Tahun 1985 tentang Mahkamah Agung, sebagaimana telah diubah terakhir dengan Undang-Undang Nomor 3 Tahun 2009 tentang Perubahan Kedua Atas Undang-Undang Nomor 14 Tahun 1985 tentang Mahkamah Agung, Lembaran Negara Republik Indonesia Tahun 2009 Nomor 3, Tambahan Lembaran Negara Republik Indonesia Nomor 4958.

Undang-Undang Nomor 12 Tahun 2011 tentang Pembentukan Peraturan Perundang-undangan, sebagaimana telah diubah dengan UndangUndang Nomor 15 Tahun 2019 tentang Perubahan Atas Undang-Undang 
Nomor 12 Tahun 2011 tentang Pembentukan Peraturan Perundangundangan, Lembaran Negara Republik Indonesia Tahun 2019 Nomor 183, Tambahan Lembaran Negara Republik Indonesia Nomor 6398.

Undang-Undang Nomor 5 Tahun 2014 tentang Aparatur Sipil Negara, Lembaran Negara Republik Indonesia Tahun 2014 Nomor 6, Tambahan Lembaran Negara Republik Indonesia Nomor 5494.

Undang-Undang Nomor 30 Tahun 2014 tentang Administrasi Pemerintahan, Lembaran Negara Republik Indonesia Tahun 2014 Nomor 292, Tambahan Lembaran Negara Republik Indonesia Nomor 5601.

Peraturan Pemerintah Nomor 53 Tahun 2010 tentang Disiplin Pegawai Negeri Sipil, Lembaran Negara Republik Indonesia Tahun 2010 Nomor 74, Tambahan Lembaran Negara Republik Indonesia Nomor 5135.

Peraturan Pemerintah Nomor 11 Tahun 2017 tentang Manajemen Pegawai Negeri Sipil, Lembaran Negara Republik Indonesia Tahun 2017 Nomor 63, Tambahan Lembaran Negara Republik Indonesia Nomor 6037.

Peraturan Mahkamah Agung Nomor 2 Tahun 2019 tentang Pedoman Penyelesaian Sengketa Tindakan Pemerintahan dan Kewenangan Mengadili Perbuatan Melanggar Hukum oleh Badan dan/atau Pejabat Pemerintahan (onrechtmatige overheidsdaad), Berita Negara Republik Indonesia Tahun 2019 Nomor 940.

\section{Peraturan Kebijakan}

Surat Keputusan Bersama Menteri Dalam Negeri, Menteri Pendayagunaan Aparatur Negara dan Reformasi Birokrasi, dan Kepala Badan Kepegawaian Negara No. 128/6597/SJ, No. 15 Tahun 2018, No. 153/KEP/2018 tentang Penegakan Hukum terhadap PNS yang telah Dijatuhi Hukuman Berdasarkan Putusan Pengadilan yang Berkekuatan Hukum Tetap karena Melakukan Tindak Pidana Kejahatan Jabatan atau Tindak Pidana Kejahatan yang Ada Hubungannya dengan Jabatan. 